\title{
Evidence-Based Reading Instruction for Individuals With Autism Spectrum Disorders
}

Kelly J. Whalon

William \& Mary

Stephanie Al Otaiba

Monica E. Delano

Follow this and additional works at: https://scholarworks.wm.edu/educationpubs

\section{Recommended Citation}

Whalon, K. J., Al Otaiba, S., \& Delano, M. E. (2009). Evidence-based reading instruction for individuals with autism spectrum disorders. Focus on autism and other developmental disabilities, 24(1), 3-16.

This Article is brought to you for free and open access by the School of Education at W\&M ScholarWorks. It has been accepted for inclusion in School of Education Articles by an authorized administrator of W\&M ScholarWorks. For more information, please contact scholarworks@wm.edu. 


\title{
Evidence-Based Reading Instruction for Individuals With Autism Spectrum Disorders
}

Kelly J. Whalon

The College of William and Mary, Williamsburg, Virginia

Stephanie Al Otaiba

Florida State University, Tallahassee

Monica E. Delano

University of Louisville, Kentucky

\begin{abstract}
Legislation mandates that all children, including children with autism spectrum disorders (ASD), be taught to read in ways that are consistent with reading research and target the five components of evidence-based reading instruction: phonemic awareness, phonics, reading fluency, vocabulary, and comprehension strategies. This review synthesized the literature on reading instruction for children with ASD that encompassed one or more of the five components of reading. The review included 11 studies with 61 participants ages 4 to 17 years. Results indicated that children with ASD can benefit from reading instruction consistent with reading research. Research in this area is still preliminary, and more research is needed to guide practice. Possible directions for future research are provided.
\end{abstract}

Keywords: autism spectrum disorders; reading; literacy

$\mathrm{G}$ enerally, converging evidence from a handful of studies describes the reading skills of children with autism spectrum disorders (ASD) as having relative strengths in decoding while experiencing greater difficulty with language and reading comprehension (Calhoon, 2001; Frith, 2003; Lord \& Paul, 1997; Nation, Clarke, Wright, \& Williams, 2006). Across two large studies involving a total of 280 participants with ASD, Mayes and Calhoun (2003a, 2003b) found that all of their participants with average IQ scores and approximately half of the children who had IQ scores below 80 achieved average scores on decoding and spelling measures. Notably, children with average IQ scores had comprehension scores within average range, but most children with IQ scores below 80 were unable to complete comprehension subtests. All participants, regardless of IQ scores, demonstrated difficulty with language comprehension.

To gain a broader understanding of the reading capabilities of children representative of the autism spectrum, Nation et al. (2006) examined the reading skills of 41 children with ASD ages 6 to 15 including 16 identified with autism, 13 with pervasive developmental disorder-not otherwise specified (PDD-NOS), and 12 with Asperger syndrome. Inclusion criteria included "measurable language skills" even if the language skills were limited. Children were assessed on measures of single-word recognition in isolation, pseudoword or nonword recognition, text reading accuracy, and text comprehension; on average, they demonstrated good word reading ability and poor comprehension. Their vocabulary and oral language comprehension scores were highly correlated with their scores on the reading comprehension measure $(.72$ and .67 , respectively). However, the authors noted large individual differences in performance, with some children scoring far above average and others unable to complete the task. This level of variance demonstrates the heterogeneity in reading ability across the autism spectrum and suggests using caution when interpreting mean scores for this population of students (Nation et al., 2006).

\footnotetext{
Authors' Note: Address correspondence to Dr. Kelly J. Whalon, College of William and Mary, P.O. Box 8795, Williamsburg, VA 23187-8795 (e-mail: kjwhal@wm.edu).
} 
Table 1

Summary of the National Reading Panel's Essential Components of Reading Instruction

\begin{tabular}{|c|c|c|}
\hline Component & Definition & Examples \\
\hline $\begin{array}{l}\text { Phonemic } \\
\text { awareness }\end{array}$ & $\begin{array}{l}\text { Recognizing and manipulating } \\
\text { spoken words in language }\end{array}$ & $\begin{array}{l}\text { Tell me: "the first sound in the word cat." /c/; "the sound that is the same } \\
\text { in tide, toy, toss." /t/; "what word these sounds make /c/ /a/ /t/?" } \\
\text { cat; "all the sounds you hear in cat?" /c/ /a/ /t/ }\end{array}$ \\
\hline Phonics & $\begin{array}{l}\text { Understanding letter-sound } \\
\text { correspondences in reading } \\
\text { and spelling }\end{array}$ & $\begin{array}{l}\text { Mapping letters to corresponding sound/phoneme and blending these } \\
\text { sounds to form words; analyzing letter-sound relationships from whole } \\
\text { to part (e.g., chop, chin, catch contain digraph ch-); segmenting words } \\
\text { into phonemes and writing corresponding letters to form words; using } \\
\text { parts of known words to identify new words; using sound-letter } \\
\text { correspondences and context cues to identify unfamiliar words in text }\end{array}$ \\
\hline $\begin{array}{l}\text { Oral reading } \\
\text { fluency }\end{array}$ & $\begin{array}{l}\text { Reading text with speed, accuracy, } \\
\text { and expression }\end{array}$ & $\begin{array}{l}\text { Repeatedly reading a text orally with guidance from the teacher } \\
\text { (choral reading, echo reading, etc.) or through independent reading } \\
\text { practice with feedback }\end{array}$ \\
\hline Vocabulary & $\begin{array}{l}\text { Understanding words read by } \\
\text { linking the word to oral } \\
\text { vocabulary }\end{array}$ & $\begin{array}{l}\text { Active learning of vocabulary required for reading a specific } \\
\text { text or likely to be seen in a variety of texts; instruction in multiple } \\
\text { contexts including making mental images of words, acting out } \\
\text { definitions, using words in writing, and searching and using } \\
\text { context clues to aid understanding }\end{array}$ \\
\hline $\begin{array}{l}\text { Comprehension } \\
\text { strategy instruction }\end{array}$ & $\begin{array}{l}\text { Directly teaching students to be } \\
\text { aware of the cognitive processes } \\
\text { involved in reading }\end{array}$ & $\begin{array}{l}\text { Teacher models monitoring reading for understanding using think aloud } \\
\text { through graphic organizers, story maps, questioning, summarization, and/or } \\
\text { multiple strategies; guided practice is provided and faded as readers } \\
\text { become increasingly more independent in using the strategies during } \\
\text { reading }\end{array}$ \\
\hline
\end{tabular}

Another study specifically examined the degree to which students with ASD could master phonics rules. Calhoon (2001) studied the word recognition skills of 10 children with autism who obtained varied IQ scores ranging from 60 to 100 and who were able to identify sight words on a second-grade level at the onset of the study. The author assessed each child's understanding of word parts, graphemes and phonemes, onsets and rime, and recognition of high-frequency words. Results indicated that the children had developed phonics skills and that they attended to word parts that provide cues, such as rimes. The author suggested phonics instruction that encompasses word families, word parts, and structural analysis (e.g., prefixes and suffixes) may prove beneficial for students with autism. Two further studies have shown that children with Asperger syndrome who developed grade-level decoding skills could comprehend material containing factual information but had trouble making inferences (Griswold, Barnhill, Myles, Hagiwara, \& Simpson, 2002; Myles et al., 2002).

The No Child Left Behind Act of 2001 (NCLB) and the Individuals with Disabilities Education Improvement Act of 2004 (IDEIA) mandate that all children, including children with ASD, be taught to read in ways that are consistent with reading research. More specifically, findings from the National Reading Panel (National Institute of Child Health and Human Development [NICHD], 2000) are cited in NCLB language requiring that all students be provided explicit and systematic classroom reading instruction that includes five essential components of reading: phonemic awareness, phonics, oral reading fluency, vocabulary, and comprehension strategies. See Table 1 for descriptions and examples of each identified component.

Although interventions including these five components have been effective in preventing or remediating reading difficulties for most children, none of these studies have included children with ASD. Findings from a recent and seminal review established the efficacy of sight word reading approaches for most students with significant cognitive disabilities, including children with autism (Browder, Wakeman, Spooner, Ahlgrim-Delzell, \& Algozzine, 2006). At present, no review has summarized the effects of interventions that target one or more of the essential components of reading mandated by the NCLB and IDEIA on the reading skills of children with ASD. Therefore, the purpose of this review is to examine the effects of such reading interventions for school-aged children with ASD.

The conceptual framework for the present review is the Simple View of Reading (Gough, Hoover, \& Peterson, 1996) as it is widely supported in the literature (Catts \& Kamhi, 2005; Kamhi, 2005; Oakhill, Cain, \& Bryant, 2003; Perfetti, Landi, \& Oakhill, 2005) and useful in categorizing the essential reading instructional components recommended by the National Reading 
Panel (NRP) into two broader sets of skills. The first set includes code-focused skills, or phonological awareness, phonics, and fluency, which are required to accurately and fluently identify words in text. The second set is comprised of meaning-focused skills, namely, vocabulary and comprehension, required for comprehending language in oral or written form.

In considering the research base on reading development of students with ASD (Calhoon, 2001; Frith, 2003; Lord \& Paul, 1997; Mayes \& Calhoun, 2003a, 2003b; Nation et al., 2006), this population of learners appears to have relative strengths in the area of phonics or decoding. However, if children with ASD can read text accurately but do not know the meaning of key vocabulary or cannot comprehend the concepts expressed, then reading comprehension will suffer. As the Simple View of Reading states, students use word recognition skills to identify written words while at the same time they are using general verbal knowledge and language comprehension abilities to construct the meaning of what they are reading (Gough et al., 1996). Because some students with ASD may experience difficulty with word-level reading, and an even greater number with reading comprehension, both code-focused and meaning-focused reading instruction are priorities. Therefore, the literature incorporating reading instruction as defined by the NCLB for children with ASD was reviewed to determine the extent to which code- and meaning-focused reading interventions affect the reading skills of children with ASD.

\section{Method}

To be included in this review, articles had to meet the following criteria: (a) published in a peer-reviewed journal, (b) include one or more school-age participants (ages 5-18 years) identified as having an ASD (i.e., autism, PDDNOS, or Asperger syndrome), and (c) describe research studies that tested the effectiveness of interventions in code-focused and/or meaning-focused skills as defined by the NRP. The search began with online ERIC and PsycINFO databases. Key words pertained to autism and reading (i.e., autism, Asperger, developmental, moderate, disabilities, reading, literacy, phonics, phonic instruction, word recognition, word identification, sight words, vocabulary, fluency, oral reading, decode, strategy instruction, comprehension). From this preliminary search, journals frequently publishing intervention research with a focus on children with ASD were identified: the Journal of Autism and Developmental Disorders, Autism, Focus on Autism and Other Developmental Disabilities, the Journal of Applied Behavior Analysis, Research and Practice for
Persons With Severe Disabilities, and Education and Training in Developmental Disabilities. These were hand searched for abstracts of interventions implemented to increase the reading skills of children with ASD. Third, references were gathered and obtained from previous literature reviews (Browder, Wakeman, et al., 2006; Conners, 1992) and book chapters (Browder, Courtade-Little, Wakeman, \& Rickelman, 2006; Houston, Al Otaiba, \& Torgesen, 2006). Studies were excluded from the review that (a) lacked a formal research design (e.g., Colasent \& Griffith, 1998; Colby, 1973; Hewett, 1964; Lanquetot, 1984), (b) provided only sight word instruction (see Browder, Wakeman et al., 2006, for a review of these studies), and/or (c) included a reading measure, but an intervention targeting a skill other than reading (e.g., visual stress in Ludlow, Wilkins, \& Heaton, 2006).

\section{Results}

A total of 11 studies met the aforementioned criteria. Table 2 shows the design, participants, setting and intervention, duration, measures, and treatment effects of each included study. Code-focused and meaning-focused interventions will be examined first, followed by interventions that combine multiple components. Implications for practitioners and directions for future research will be discussed.

Of the 11 studies, 4 targeted code-focused skills (Basil \& Reyes, 2003; Coleman-Martin, Heller, Chihak, \& Irvine, 2005; Heimann, Nelson, Tjus, \& Gillberg, 1995; Tjus, Heimann, \& Nelson, 1998), 5 targeted meaningfocused skills (Dugan et al., 1995; Kamps, Leonard, Potucek, \& Garrison-Harrell, 1995; O’Conner \& Klein, 2004; Rosenbaum \& Breiling, 1976; Whalon \& Hanline, 2008), and the remaining 2 studies addressed both codefocused and meaning-focused skills (Kamps, Barbetta, Leonard, \& Delquadri, 1994; Kamps, Locke, Delquadri, \& Hall, 1989). In all, 61 children with ASD participated, including $44(72 \%)$ identified with autism, 5 (8\%) with high-functioning autism (HFA), 7 (12\%) with Asperger syndrome, and 5 (8\%) with PDD-NOS. Participants ranged in age from 4 to 17 years.

\section{Code-Focused Interventions}

Four studies addressed the question of whether codefocused interventions can improve the reading ability of students with ASD (Basil \& Reyes, 2003; ColemanMartin et al., 2005; Heimann et al., 1995; Tjus et al., 1998). Each of these studies used computer-assisted instruction with a pretest/posttest design. Three shared the 
Table 2

Reviewed Studies by Instructional Focus

\begin{tabular}{|c|c|c|c|c|c|c|}
\hline Author & Design & Participants & $\begin{array}{l}\text { Setting and } \\
\text { Intervention }\end{array}$ & Duration & Measures & $\begin{array}{l}\text { Treatment } \\
\text { Effects }\end{array}$ \\
\hline \multicolumn{7}{|c|}{ Code-focused studies } \\
\hline $\begin{array}{l}\text { Basil \& } \\
\text { Reyes } \\
\text { (2003) }\end{array}$ & $\begin{array}{l}\text { Pre/posttest } \\
\text { design }\end{array}$ & $\begin{array}{l}2 \text { students with ASD } \\
\text { 1.13-year-old, } \\
\text { MA = 4 years, reading: } \\
\text { limited sight word } \\
\text { reading/writing } \\
\text { 2. } 8 \text {-year-old with } \\
\text { intellectual disability, } \\
\text { MA: = 7 years, reading: } \\
\text { limited sight word } \\
\text { reading/writing, } \\
\text { described as difficult to } \\
\text { involve in reading tasks }\end{array}$ & $\begin{array}{l}\text { Self-contained } \\
\text { classroom (Spain) } \\
\text { One-to-one } \\
\text { computer-assisted } \\
\text { instruction. }\end{array}$ & $\begin{array}{l}30 \text { min, twice } \\
\text { a week for } 3 \\
\text { months; } \\
\text { total }=12 \mathrm{hr} .\end{array}$ & $\begin{array}{l}\text { End of } \\
\text { lesson } \\
\text { test. } \\
\text { Spanish dictation, } \\
\text { standardized } \\
\text { test measuring } \\
\text { writing (i.e., } \\
\text { dictation, free } \\
\text { composition, } \\
\text { copying) and } \\
\text { reading (i.e., } \\
\text { letters, syllables, } \\
\text { words, text, } \\
\text { comprehension). }\end{array}$ & $\begin{array}{l}\text { Mastered all } 10 \text { lessons } \\
\text { and passed the end-tests } \\
\text { at the end of } 3 \text { months. } \\
\text { One participant } \\
\text { demonstrated gains } \\
\text { in PA, word spelling, } \\
\text { and spontaneous written } \\
\text { composition on } \\
\text { standardized measure. }\end{array}$ \\
\hline $\begin{array}{l}\text { Coleman- } \\
\text { Martin, } \\
\text { Heller, } \\
\text { Chihak, } \\
\text { \& Irvine } \\
\text { (2005) }\end{array}$ & $\begin{array}{l}\text { Multiple } \\
\text { conditions } \\
\text { design with } \\
\text { drop-down } \\
\text { baselines }\end{array}$ & $\begin{array}{l}\text { One 12-year-old with ASD, } \\
\text { MA: NR, reading: } \\
\text { informal assessments } \\
\text { indicated second- } \\
\text { grade-level word } \\
\text { recognition skills }\end{array}$ & $\begin{array}{l}\text { Self-contained } \\
\text { classroom. } \\
\text { One-to-one } \\
\text { computer- } \\
\text { assisted sight } \\
\text { word instruction. }\end{array}$ & $\begin{array}{l}\text { Instruction } \\
\text { provided } \\
\text { until } 80 \% \\
\text { correct for } 2 \\
\text { consecutive } \\
\text { sessions. } \\
\text { Minimum } \\
\text { of } 4 \text { sessions; } \\
\text { total = NR. }\end{array}$ & $\begin{array}{l}\text { Sight word measure } \\
\text { (identified a target } \\
\text { word from three } \\
\text { teacher-only } \\
\text { similar distracter } \\
\text { words). }\end{array}$ & $\begin{array}{l}\text { Criterion reached in } \\
3 \text { sessions in } \\
\text { computer-assisted } \\
\text { condition, in } 4 \\
\text { sessions during } \\
\text { condition, and in } 6 \\
\text { sessions during } \\
\text { teacher + computer } \\
\text { condition. }\end{array}$ \\
\hline $\begin{array}{l}\text { Heimann, } \\
\text { Nelson, } \\
\text { Tjus, \& } \\
\text { Gillberg } \\
\text { (1995) }\end{array}$ & $\begin{array}{l}\text { Pre/posttest } \\
\text { with } \\
\text { follow-up }\end{array}$ & $\begin{array}{l}11 \text { children with ASD } \\
\text { Mean CA }=9.4 \text { years } \\
\text { (range }=6-13 \text { years }) \\
\text { Mean MA }=7 \text { years } \\
(S D=2) \\
\text { Reading: NR }\end{array}$ & $\begin{array}{l}\text { Self-contained } \\
\text { school (Sweden). } \\
\text { One-to-one } \\
\text { computer-assisted } \\
\text { instruction. }\end{array}$ & $\begin{array}{l}\text { Averaged } 26 \\
\text { sessions } \\
\text { (range } 21-32 \\
\text { min); } \\
\text { approximate } \\
\text { total = } 13 \mathrm{hr} \text {. }\end{array}$ & $\begin{array}{l}\text { End of lesson test. } \\
\text { Swedish } \\
\text { standardized } \\
\text { test of PA, word } \\
\text { identification, } \\
\text { sentence reading, } \\
\text { and sentence } \\
\text { imitation. } \\
\text { Observations of } \\
\text { communication. }\end{array}$ & $\begin{array}{l}\text { Completed end-of-lesson } \\
\text { tests with a mean of } \\
92 \% \text { correct and } S D \text { of } \\
8.4 \text {. } \\
\text { Increased mean scores on } \\
\text { reading measures from } \\
\text { pre- to posttest and at } \\
\text { follow-up; increased } \\
\text { mean scores on PA } \\
\text { measures from pre- to } \\
\text { posttest, but decreased } \\
\text { at follow-up; sentence } \\
\text { imitation results } \\
\text { inconclusive. } \\
\text { Observations revealed } \\
\text { increased interaction } \\
\text { during intervention. }\end{array}$ \\
\hline $\begin{array}{l}\text { Tjus, } \\
\text { Heimann, } \\
\& \\
\text { Nelson } \\
(1998)\end{array}$ & $\begin{array}{l}\text { Pre/posttest } \\
\quad \text { with } \\
\text { follow-up }\end{array}$ & $\begin{array}{l}13 \text { students with ASD } \\
\text { Mean CA }=10 \text { years } \\
\text { (range }=4-11 \text { years) } \\
\text { Mean MA }=7.3 \text { years } \\
\quad(S D=2) \\
\text { Reading: NR }\end{array}$ & $\begin{array}{l}\text { Self-contained } \\
\text { classroom (Sweden). } \\
\text { One-to-one } \\
\text { computer-assisted } \\
\text { instruction. }\end{array}$ & $\begin{array}{l}\text { Averaged } 15 \\
\text { sessions } \\
\text { (range } 15-30 \\
\text { min); } \\
\text { approximate } \\
\text { total }=7.5 \mathrm{hr} \text {. }\end{array}$ & $\begin{array}{l}\text { End of lesson test. } \\
\text { Swedish } \\
\text { standardized } \\
\text { test of PA, word } \\
\text { identification, } \\
\text { sentence reading, } \\
\text { and sentence } \\
\text { imitation. }\end{array}$ & $\begin{array}{l}\text { Increased mean scores } \\
\text { from pre- to posttest } \\
\text { on reading measures; } \\
\text { decline at follow-up; } \\
\text { increased mean scores } \\
\text { on PA from pre- to } \\
\text { posttest and at } \\
\text { follow-up; proportion } \\
\text { of correct sentences } \\
\text { increased minimally, } \\
\text { but response time } \\
\text { significantly decreased. }\end{array}$ \\
\hline
\end{tabular}


Table 2 (continued)

\begin{tabular}{|c|c|c|c|c|c|c|}
\hline Author & Design & Participants & $\begin{array}{l}\text { Setting and } \\
\text { Intervention }\end{array}$ & Duration & Measures & $\begin{array}{l}\text { Treatment } \\
\text { Effects }\end{array}$ \\
\hline \multicolumn{7}{|c|}{ Meaning-focused studies } \\
\hline $\begin{array}{l}\text { O'Connor } \\
\text { \& Klein } \\
\text { (2004) }\end{array}$ & $\begin{array}{l}\text { Repeated } \\
\text { measures } \\
\text { within-subjects } \\
\text { design }\end{array}$ & $\begin{array}{l}20 \text { children with ASD, } \\
10 \text { with autism, } 6 \text { with } \\
\text { Asperger syndrome, and } \\
4 \text { with PDD-NOS } \\
\text { Mean age = } 15 \text { years, } \\
\text { range = 14-17 years; } \\
S D=1 \text {; reading: all } \\
\text { participants had average } \\
\text { or above decoding skills } \\
\text { but lower levels of } \\
\text { reading comprehension }\end{array}$ & $\begin{array}{l}\text { Home or school setting. } \\
\text { One-to-one instruction. } \\
\text { Students read stories } \\
\text { aloud under two } \\
\text { control and three } \\
\text { treatment conditions: } \\
\text { prereading question, } \\
\text { anaphoric cuing, } \\
\text { cloze. }\end{array}$ & $\begin{array}{l}\text { 10-min } \\
\text { conditions; } \\
\text { total = } 1 \mathrm{hr}\end{array}$ & $\begin{array}{l}\text { Researcher-made } \\
\text { test of } \\
\text { comprehension } \\
\text { questions. }\end{array}$ & $\begin{array}{l}\text { Anaphoric cuing resulted } \\
\text { in medium effect size } \\
\text { gains (.5 } S D \text { above } \\
\text { results in control } \\
\text { condition) of more than } \\
\text { half of participants. } \\
\text { Gains from prereading } \\
\text { questions and cloze } \\
\text { conditions were small } \\
\text { and not statistically } \\
\text { significant. }\end{array}$ \\
\hline $\begin{array}{l}\text { Rosenbaum } \\
\quad \& \\
\text { Breiling } \\
\text { (1976) }\end{array}$ & $\begin{array}{l}\text { ABA } \\
\text { reversal } \\
\text { design }\end{array}$ & $\begin{array}{l}\text { 12-year-old female with } \\
\text { ASD, MA and IQ: NR, } \\
\text { reading: limited decoding } \\
\text { ability and comprehension }\end{array}$ & $\begin{array}{l}\text { Clinical setting. } \\
\text { One-to-one instruction } \\
\text { in reading directions } \\
\text { (e.g., stand up, point } \\
\text { to your mouth, point } \\
\text { to the man writing) } \\
\text { presented for 10-s } \\
\text { trials. }\end{array}$ & $\begin{array}{l}\text { Initially } 17 \text { daily } \\
\text { 15-20-min } \\
\text { sessions, } \\
\text { followed by } 17 \\
\text { twice a day } \\
\text { sessions; } \\
\text { approximate } \\
\text { total }=15 \mathrm{hr} \text {. }\end{array}$ & $\begin{array}{l}\text { Researcher-made } \\
\text { observational } \\
\text { recording } \\
\text { scale based on } \\
\text { level of prompting } \\
\text { required for a } \\
\text { correct response. }\end{array}$ & $\begin{array}{l}100 \% \text { mastery by } 12 \text { th } \\
\text { session and maintained } \\
\text { when reward removed; } \\
\text { generalized across } \\
\text { experimenters and } \\
\text { conditions, except } \\
\text { when researcher absent, } \\
\text { but when reentered } \\
\text { room performance } \\
\text { near } 100 \% \text {. }\end{array}$ \\
\hline
\end{tabular}


Table 2 (continued)

\begin{tabular}{|c|c|c|c|c|c|c|}
\hline Author & Design & Participants & $\begin{array}{l}\text { Setting and } \\
\text { Intervention }\end{array}$ & Duration & Measures & $\begin{array}{l}\text { Treatment } \\
\text { Effects }\end{array}$ \\
\hline $\begin{array}{c}\text { Whalon \& } \\
\text { Hanline } \\
\text { (2008) }\end{array}$ & $\begin{array}{l}\text { Multiple } \\
\text { baseline } \\
\text { across } \\
\text { participants }\end{array}$ & $\begin{array}{l}3 \text { children with ASD } \\
\text { 1. 7-year-old with } \\
\text { Asperger syndrome, } \\
\text { IQ = 101, reading: } \\
\text { difficulty with retell } \\
\text { 2. 8-year-old with ASD, } \\
\text { nonverbal IQ = } 112 \\
\text { 3. 7-year-old with PDD-NOS, } \\
\text { nonverbal IQ = 92, reading: } \\
\text { difficulty with retell }\end{array}$ & $\begin{array}{l}\text { Small group setting } \\
\text { outside of general } \\
\text { education classroom. } \\
\text { Reciprocal questioning } \\
\text { in cooperative pairs. }\end{array}$ & $\begin{array}{l}\text { 30-40 min, } 4 \\
\text { days a week } \\
\text { for } 3 \text { weeks; } \\
\text { approximate } \\
\text { total }=7 \mathrm{hr} \text {. }\end{array}$ & $\begin{array}{l}\text { Frequency of question } \\
\text { generation and } \\
\text { unprompted } \\
\text { responses } \\
\text { to questions } \\
\text { generated } \\
\text { by peers. } \\
\text { Participant } \\
\text { satisfaction survey. }\end{array}$ & $\begin{array}{l}\text { Increased generation of and } \\
\text { response to questions. } \\
\text { Prompting occurred } \\
\text { throughout intervention } \\
\text { but decreased. } \\
\text { Questions became less } \\
\text { generic and more } \\
\text { varied and specific. } \\
\text { Participants perceived } \\
\text { the intervention as } \\
\text { helpful, and parents } \\
\text { noted a difference in } \\
\text { their child's reading. }\end{array}$ \\
\hline
\end{tabular}

\begin{tabular}{|c|c|c|c|c|c|c|}
\hline \multicolumn{7}{|c|}{ Multicomponent studies } \\
\hline $\begin{array}{l}\text { Kamps, } \\
\text { Barbetta, } \\
\text { Leonard, } \\
\& \\
\text { Delquadri } \\
(1994)\end{array}$ & $\begin{array}{l}\text { Multiple } \\
\text { baseline } \\
\text { across } \\
\text { participants }\end{array}$ & $\begin{array}{l}3 \text { children with HFA } \\
\text { 1. 8-year-old, IQ = 101, } \\
\text { first/second-grade } \\
\text { classroom, reading: at or } \\
\text { above second-grade level } \\
\text { 2. 8-year-old, IQ = 71, } \\
\text { second grade, reading: } \\
\text { second grade but } \\
\text { difficulty with reading } \\
\text { comprehension } \\
\text { and completing tasks } \\
\text { 3. 9-year-old, IQ NR, } \\
\text { third grade, reading: } \\
\text { grade level on most } \\
\text { academic tasks }\end{array}$ & $\begin{array}{l}\text { General education } \\
\text { first/second-, } \\
\text { second-, and } \\
\text { third-grade } \\
\text { classrooms. } \\
\text { Classwide } \\
\text { peer tutoring. }\end{array}$ & $\begin{array}{l}\text { 25-30 min, three } \\
\text { to four times } \\
\text { per week. } \\
\text { Number of } \\
\text { sessions varied } \\
\text { (range }=14-35 \\
\text { sessions); total } \\
\text { = unclear or a } \\
\text { range of } 6-17 \mathrm{hr} \text {. }\end{array}$ & $\begin{array}{l}\text { Researcher-made } \\
\text { measures of words } \\
\text { read correctly per } \\
\text { minute (and errors); } \\
\text { response to } \\
\text { comprehension } \\
\text { questions. } \\
\text { Duration of } \\
\text { social interaction } \\
\text { (i.e., initiation- } \\
\text { response sequence). }\end{array}$ & $\begin{array}{l}\text { Participants increased } \\
\text { mean number of words } \\
\text { read correctly per } \\
\text { minute (19,31, and } \\
12 \text { words). } \\
\text { Number of errors } \\
\text { decreased by } 1 \text { student } \\
\text { (from } 6 \text { to } 2 \text { ) and } \\
\text { remained low at 2-3 } \\
\text { words per minute for } \\
\text { the other } 2 \text { participants. } \\
\text { Participants increased the } \\
\text { percentage of correct } \\
\text { responses to } \\
\text { comprehension } \\
\text { questions (47\%, 24\%, } \\
\text { and } 67 \% \text { at baseline to } \\
76 \%, 68 \% \text {, and 90\%). } \\
\text { Increased duration of } \\
\text { social communication. }\end{array}$ \\
\hline $\begin{array}{l}\text { Kamps, } \\
\text { Locke, } \\
\text { Delquadri, } \\
\text { \& Hall } \\
\text { (1989) }\end{array}$ & $\begin{array}{l}\text { Multiple } \\
\text { baseline } \\
\text {, across tasks }\end{array}$ & $\begin{array}{l}2 \text { children with autism } \\
\text { 1. } 9 \text {-year-old, } \mathrm{IQ}=50, \\
\text { reading: good decoding } \\
\text { but poor comprehension } \\
\text { 2. } 11 \text {-year-old, } \mathrm{IQ}=50 \text { and } \\
\text { 50, reading: good decoding } \\
\text { but poor comprehension }\end{array}$ & $\begin{array}{l}\text { Self-contained } \\
\text { fifth-grade } \\
\text { general education } \\
\text { class. } \\
\text { Peer tutoring in money } \\
\text { skills, expressive } \\
\text { language, and oral } \\
\text { reading/ } \\
\text { comprehension. } \\
\text { Oral reading fluency } \\
\text { and comprehension. }\end{array}$ & $\begin{array}{l}20 \text { min three } \\
\quad \text { times a } \\
\text { week for } \\
\text { approximately } \\
6 \text { weeks; } \\
\text { total = } \\
\text { approximately } \\
\text { 5-6 hr. }\end{array}$ & $\begin{array}{l}\text { Number of words read } \\
\text { correctly and errors } \\
\text { per minute from a } \\
\text { 2-min timed reading. } \\
\text { Number of correct } \\
\text { responses to factual } \\
\text { comprehension } \\
\text { questions. }\end{array}$ & $\begin{array}{l}\text { Participant mean reading } \\
\text { rates increased } \\
\text { following intervention } \\
(M=19.6 \text { and } 30.2 \text { at } \\
\text { baseline to } 34.2 \text { and } \\
\text { 39.7), and the number } \\
\text { of errors decreased } \\
(M=3.7 \text { and } 1.9 \text { at } \\
\text { baseline to } 1.3 \text { and } 0.9) \text {. } \\
\text { Participants increased the } \\
\text { number of correct } \\
\text { responses to factual } \\
\text { comprehension } \\
\text { questions (1.9 and } 1.3 \\
\text { at baseline to } 3.8 \\
\text { and 3.5). }\end{array}$ \\
\hline
\end{tabular}

Note: $\mathrm{ASD}=$ autism spectrum disorders; $\mathrm{CA}=$ cognitive age; $\mathrm{HFA}=$ high-functioning autism; $\mathrm{MA}=$ mental age; $\mathrm{NR}=$ not reported; $\mathrm{PA}=$ phonological awareness; PDD-NOS = pervasive developmental disorder-not otherwise specified.

same software, developed in Sweden, which evolved from an early version called "Alpha" (Heimann et al., 1995) to a later version called "Delta" (Basil \& Reyes, 2003; Tjus et al., 1998). The program administered in the Basil and Reyes study was changed from Swedish to accommodate students speaking Castilian Spanish. The program includes 10 lessons that teach students to build sentences in growing difficulty by clicking on a word or group of words. Once a sentence is created, a corresponding picture is generated, students click on the sentence, and the 
program reads the sentence aloud. This is an errorless learning task in that all possible words the child could select form a meaningful sentence that can be animated. This task builds in complexity beginning with noun and verb sentences and adding prepositions, adjectives, and conjunctions in future lessons. The program also includes a computer-delivered assessment task (used in each study as one of the pretest/posttest measures) that requires participants to create a sentence representing a presented animated action from a choice of preselected words at $80 \%$ accuracy.

Heimann et al. (1995) provided training to 30 children, including 11 with ASD. The intervention was conducted across 3 to 4 months. Results suggested that on average students mastered the computer-assisted task and also increased their reading and phonological scores on researcher-administered standardized tests with some maintenance at follow-up.

Tjus et al. (1998) targeted only students with ASD. In this study, students received fewer sessions (15) conducted over a briefer time frame (1-2 months). Similar to the earlier study, students mastered the computer-assisted task and achieved generally positive gains with some demonstration of maintenance in phonological awareness.

The findings from both of these studies (Heimann et al., 1995; Tjus et al., 1998) are encouraging, yet ambiguous. Because of the small sample size, age range of included participants, absence of information describing participant reading ability prior to the intervention, and the variable reading skills associated with ASD (Nation et al., 2006), mean scores can obscure findings. Thus, it is possible that reporting means could mask important and potentially large individual differences in response to intervention.

In the third computer study (Basil \& Reyes, 2003), two students successfully completed 10 lessons and passed the computer-assisted task with $80 \%$ accuracy or better. However, only one student was administered the posttest battery; the other "did not cooperate in the test tasks" (Basil \& Reyes, 2003, p. 40). Thus, findings for only one student suggest improvement from pretest to posttest on measures of phonological awareness and spelling.

The fourth study (Coleman-Martin et al., 2005) used a single-subject design to determine the effectiveness of the nonverbal reading approach delivered through computerassisted instruction on participants' ability to decode new words. This study was conducted in English in the United States. One student with autism was taught phonic skills across three conditions: (a) teacher only, (b) teacher plus computer-assisted instruction, and (c) computer-assisted instruction alone. In all three conditions, the teaching method was constant, but differed in the mode of instruction. First, the teacher taught the whole word (man), and then the teacher segmented the word by stretching out each individual sound (e.g., mmmmaaaannnn). In the final step, the teacher showed the student the whole word again and asked the student to say it fast. The process was the same during the computer-assisted condition except that instruction was delivered through PowerPoint. Throughout each step, the teacher or computer verbalized the word as the student was instructed to use internal speech, or to say the sound "in your head" (Coleman-Martin et al., 2005, p. 84). As in the prior three studies, the scope of training was limited; a total of only 15 words were taught, with 5 included in each condition. The findings suggest that computer-assisted instruction may be a promising and flexible way to provide children with autism additional decoding practice.

In summary, in these four code-focused computerassisted instruction studies, the authors reported gains across a variety of code-reading skills and spelling measures, including phonological awareness (Basil \& Reyes, 2003; Heimann et al., 1995; Tjus et al., 1998), word recognition (Basil \& Reyes, 2003; Coleman-Martin et al., 2005; Heimann et al., 1995; Tjus et al., 1998), word spelling (Basil \& Reyes, 2003), sentence reading (Heimann et al., 1995; Tjus et al., 1998), and sentence imitation (Heimann et al., 1995; Tjus et al., 1998). These results suggest that children with ASD can develop phonemic awareness and/or phonics skills regardless of IQ score (Tjus et al., 1998). However, it is important to consider that the Swedish and Spanish languages are more transparent than English, so more replications are needed with English.

Consistent across all included studies were gains made by children with ASD in code-focused skills. The duration or intensity of instruction needed for children with ASD to master skills is less clear. Participants who received instruction through Delta Messages did not receive direct instruction in phonemic awareness or phonics, yet they made incidental gains on phonological awareness and phonics measures. It may be possible that the degree and intensity of phonological awareness and phonics instruction provided to the general education population, and consistent with the NRP recommendations, may be sufficient for some children with ASD.

\section{Meaning-Focused Interventions}

Five studies investigated the impact of meaning-focused interventions on the reading skills of participants with ASD. Two targeted vocabulary (Dugan et al., 1995; Rosenbaum \& Breiling, 1976), two comprehension (O'Connor \& Klein, 2004; Whalon \& Hanline, 2008), and one vocabulary and comprehension (Kamps et al., 1995). Across these five studies, two instructional delivery methods 
were used: peer-mediated (Dugan et al., 1995; Kamps et al., 1995; Whalon \& Hanline, 2008) and one-to-one (O’Connor \& Klein, 2004; Rosenbaum \& Breiling, 1976). Participants in all five studies were students with ASD described as having word recognition skills of at least a second-grade level and experiencing problems with reading comprehension.

Dugan et al. (1995) formed cooperative groups in an inclusive fourth-grade social studies class. Each group consisted of one high academic achiever, two moderate-level achievers, and one below-level achiever or one of the two students with ASD. The authors described one participant with ASD as "high functioning" and the other as "functioning at a moderate level" (Dugan et al., 1995, p. 177). Cooperative learning groups followed a 10-min social studies lecture and included keyword peer tutoring for $10 \mathrm{~min}$, fact card tutoring for $8 \mathrm{~min}$, and a 5-min team worksheet or research activity. Groups occurred four times a week for 3 weeks during a 40-min social studies class and again for 5 weeks following a reversal to baseline conditions. Weekly quizzes tested each participant's ability to identify and use 15 key vocabulary terms in a grammatically correct sentence to include the keyword and a referent to that term. When asked about satisfaction with the intervention, teachers reported high levels regarding ease of implementation and social benefits of the intervention, but reports of academic gains were mixed as one teacher indicated dissatisfaction with the academic progress of students with ASD.

Although the intervention produced positive gains, the authors reported low reliability when participants exhibited few social interaction and engagement behaviors and on some social studies quiz items. The mean percentage of interobserver agreement on target students' social studies quizzes was $63 \%$. The authors explained that although reliability was acceptable for most items, items that required students to make inferences resulted in lower levels of agreement (Dugan et al., 1995).

Kamps et al. (1995) also incorporated cooperative learning groups. Participants with ASD included one child identified with HFA and two children with autism and a moderate cognitive disability. While in cooperative learning groups, participants completed three 10-min learning activities based on a novel. Teacher-led instruction followed cooperative learning groups and focused on new vocabulary, reading a story, main ideas, and sequencing. The participant with HFA participated in teacher-led instruction, and students with autism were given independent tasks based on their separate reading material. The participant identified as having HFA responded to both fact- and inferential-based questions, and participants with autism were administered only fact-based items.
Kamps et al. (1995) did not report the number of factbased and inferential items or vocabulary and comprehension questions posed to students. In addition, reported results do not mention student performance on fact-based versus inferential questions. Also, because only factbased items were administered to participants with autism and a moderate cognitive disability, their ability to respond to inference-related questions is unknown.

Whalon and Hanline (2008) randomly assigned participants with ASD to one of three general education peers $(n=9)$ from their mainstream classroom setting to work in cooperative pairs. On each successive day, general education participants were rotated. In cooperative pairs, students were taught to generate and respond to "wh-" questions using a story grammar framework (i.e., setting, characters, events, problem, and solution) as they took turns reading a book aloud. During the initial session, the researchers used a think-aloud procedure to teach question generation by verbally walking the students through each mental process used to construct a question during reading. During the initial session, the researcher and participants took turns generating and responding to questions. By Session 2, the researcher no longer generated questions with participants, and participants monitored their participation through the use of a visual checklist and an interactive visual storyboard. The researcher provided praise following appropriate question generation and responding, and scaffolding to include verbal prompts, corrective feedback, and modeling when participants had difficulty forming or responding to questions. Verbal prompting included a verbal reminder to generate or respond to a question, and when giving corrective feedback the researcher explained why a question or response was unclear or inappropriate and modeled an appropriate question and response.

Gains were immediate for two participants, and the participant with PDD-NOS showed greater variability. Levels of prompting were similar among participants with ASD and their peers. For example, both participants with ASD and their general education peers required more prompting when a question required an answer beyond text recall or what was explicitly stated in the text. Measures of treatment fidelity reveal the intervention was implemented as intended. Despite positive results, the lack of a generalization measure makes it unclear whether student gains would be realized on a distant curriculum-based assessment (e.g., a weekly pretest and posttest or story retell after completing a book).

The two one-on-one studies used very different approaches to enhance understanding of text. Rosenbaum and Breiling (1976) taught a girl with autism to demonstrate understanding of a single direction presented on an 
index card by acting out the action or pointing to a picture of someone completing the action. When the participant successfully interpreted the action, the researcher provided praise and candy. Following an incorrect response, the researcher provided a series of prompts until the participant responded correctly: (a) a verbal prompt, (b) model of the correct response, and (c) physical guidance. Despite mastery of the 54 tasks, it is unclear how the participant would respond to similar words read in connected text.

O'Conner and Klein (2004) sought to determine the effects of procedural facilitation on the reading comprehension of participants with ASD. All participants achieved high scores on word identification and low scores on reading comprehension measures. Participants were asked to read five stories aloud in four conditions. In the prereading condition, researchers asked students questions before reading to access prior knowledge. On anaphoric cuing passages, pronouns were underlined and participants identified the referent from a choice of three words written under the corresponding pronoun. Similarly, in the cloze condition, students read a passage with 12 blanks and selected a word to fill in the blank from a choice of three words (other than a pronoun) that could be deduced from information in the previous three sentences. Students wrote the chosen word in each blank. In control conditions, the participants read the passages without any additional prompts or cues. Following each condition, a researchermade test consisting of 12 items (e.g., free retell, identification of main idea, title generation, answering fact-based and inference questions) was administered.

Results showed that more than half of the participants with ASD increased performance on the comprehension test under the anaphoric cuing condition but not the prereading questions and cloze conditions. The authors noted that in the activating prior knowledge condition, participants responded to questions with information inconsistent with the present reading, which possibly not only failed to enhance comprehension but actually impeded comprehension. Also, in both the anaphoric cuing and cloze conditions, the participants completed the task with approximately $80 \%$ accuracy, but gains were greater following anaphoric cuing.

These findings suggest that anaphoric cuing is a promising reading comprehension intervention, and the authors note that students with ASD can potentially be taught to use the strategy independently. Based on the findings of this study, it may be necessary to initially provide greater structure when teaching a comprehension strategy to children with ASD. That is, in the anaphoric cuing condition, students were briefly taught that texts contain shorter words that represent longer words. Students were given a choice of words representing the pronoun and were asked to circle the one that corresponded to the "shortcut" word (O'Connor \& Klein, 2004, p. 120); therefore, more structure was provided by presenting options rather than an open-ended prompt (i.e., cloze procedure, prior knowledge questions). Additional research is needed to understand the degree of support needed for children with ASD to learn a comprehension strategy as well as a method for fading such supports.

In summary, despite some individual variability, following participation in meaning-focused interventions, students with ASD made gains on vocabulary and/or comprehension quizzes (Dugan et al., 1995; Kamps et al., 1995), question generation and responding during reading (Whalon \& Hanline, 2008), ability to follow written directions (Rosenbaum \& Breiling, 1976), and retelling the important events of a story (O'Connor \& Klein, 2004). Additional benefits were noted for general education peers in peer-mediated studies (Dugan et al., 1995; Kamps et al., 1995; Whalon \& Hanline, 2008). Although measured in only three studies, social validity reports from teachers (Dugan et al., 1995; Kamps et al., 1995), participants with ASD, their peers, and parents (Whalon \& Hanline, 2008) indicated some perceived benefit after children with ASD participated in meaning-focused interventions. Furthermore, results showed potential for interactive reading interventions such as cooperative learning to target additional, important skills for children with ASD such as social communication (Kamps et al., 1995) and academic engagement (Dugan et al., 1995; Kamps et al., 1995).

Although results suggest that students with ASD can develop meaning-focused skills, some variability was reported and attributed to individual characteristics. For example, in one study, participants with autism and a moderate cognitive disability did not receive the same benefits from interventions as their peer identified with HFA (Kamps et al., 1995). Also, the majority of meaningfocused studies included participants identified with high-functioning forms of autism ( $n=23$ of 29). Whalon and Hanline (2008) reported that gains made following an interactive reading comprehension intervention reflected the degree of participant language development prior to intervention. Specifically, participants achieving higher scores on language assessments prior to intervention experienced more immediate gains.

\section{Multicomponent Interventions}

Two studies incorporated multicomponent interventions to increase the code-focused and meaning-focused skills of children with ASD. Kamps et al. (1989) measured the effectiveness of peer tutors for increasing the academic skills of two children with autism described as 
having good decoding but poor comprehension skills. When targeting reading, participants with autism read aloud to their general education peers and answered comprehension questions based on what was read. Results indicated the benefits of the intervention.

In a similar study, Kamps et al. (1994) evaluated the impact of classwide peer tutoring on the fluency and reading comprehension as well as social interaction skills of children with HFA and average academic skills. Students were assigned to a different peer tutor weekly, and tutoring roles were reciprocal. Students took turns repeatedly reading, providing corrective and positive feedback, and asking 3 min of wh- comprehension questions. The number of words read correctly per minute were recorded and posted in the classroom. Bonus points were given for appropriate tutor-learner behaviors, and free time followed tutoring to provide participants with an opportunity for social interaction. Following classwide peer tutoring, participants with HFA increased the mean number of words read correctly per minute. A return to baseline resulted in a decrease for two participants, but rates increased once classwide peer tutoring was reintroduced and exceeded baseline levels.

Like the cooperative learning study conducted by Kamps et al. (1995) targeting comprehension skills, the peer-tutoring studies addressing both fluency and comprehension varied their outcome measure based on the characteristics of participants with ASD. When participants with ASD were described as high functioning, outcome measures included both fact-based and inferential questions (Kamps et al., 1994), but when participants with autism were described as having a cognitive disability, measures were comprised of fact-based items only (Kamps et al., 1989). Also, consistent with the cooperative learning study, the number of inferential and fact-based questions administered was not specified, making it difficult to interpret the extent to which participants made gains on factversus inference-based questions (Kamps et al., 1994).

In summary, peer-mediated studies addressing the oral reading fluency and comprehension of children with ASD resulted in increased number of words read correctly per minute and comprehension questions answered correctly (Kamps et al., 1989; Kamps et al., 1994). Also, the classwide peer-tutoring intervention revealed gains in duration of social communication for both children with ASD and their general education peers (Kamps et al., 1994). Results from these studies suggest that children with ASD can benefit from peer-mediated interventions to increase their oral reading fluency as well as their ability to respond to comprehension questions in a relatively short amount of time (i.e., duration of interventions was 5-17 hr).

\section{Discussion}

The Simple View consists of two distinct components, decoding and language comprehension, that together achieve reading comprehension. Children with ASD are often considered to be good rule-based or rote learners (Frith, 2003; Sigman, Dissanayake, Arbelle, \& Ruskin, 1997), and as a result, phonics (i.e., decoding) may be a strength relative to meaning-focused skills. Research investigating the reading development of children with ASD indicates that similar to language development (Minshew, Goldstein, \& Siegel, 1995), when children with ASD develop reading skills, they can demonstrate good mechanics of reading or code-focused skills (i.e., word identification; Frith, 2003; Lord \& Paul, 1997; Minshew, Goldstein, Taylor, \& Siegel, 1994). Yet consistent reports that children with ASD experience reading comprehension difficulties (Mayes \& Calhoun, 2003a, 2003b; Minshew et al., 1994; Nation et al., 2006; Wahlberg \& Magliano, 2004) make it probable that despite good word recognition ability, many children with ASD will experience some difficulties with reading comprehension.

Because of the unstable reading profile associated with ASD (Nation et al., 2006), some learners will have difficulty developing both word reading and comprehension skills. Therefore, it is important that reading instruction emphasize both code- and meaning-focused skills. Although limited in number and variable in quality, the reviewed studies indicate that children with ASD can benefit from instruction in the five areas of reading recommended by the NRP as well as NRP-advocated strategies. In combination these studies yield support for comprehensive reading instruction to include the five areas of reading with a focus on reading and language comprehension in the early grades.

Children with ASD may benefit from phonics instruction consistent with the NRP and offered through the general education curriculum. For example, the NRP suggested teaching students how to identify sounds in words (i.e., phonemic awareness), map those sounds to each corresponding letter (i.e., phonics), and blend those sounds together to form words (NICHD, 2000). This approach is used in many comprehensive commercial reading programs (e.g., Reading Mastery, Open Court) and is similar to the nonverbal reading approach utilized in the Coleman et al. study (2005). Such approaches are direct and should be taught systematically by introducing all primary soundletter relationships in a logical and sequential manner (e.g., teaching individual consonant and vowel letter-sound relationships prior to blends and digraphs; Ehri, 2004). 
Furthermore, the NRP recommended authentic practice with developing code-focused skills in a number of different contexts that include connected text so that decoding is not interpreted as an isolated skill but rather part of the reading process (Ehri, 2004). One possible method or context for practicing code-focused skills is to supplement general education instruction with computerassisted instruction. All four reviewed studies addressing code-focused skills utilized computer-assisted instruction, and results were promising, suggesting that this method is a viable instructional modality. Evidence is insufficient to advocate using computer-assisted instruction as a sole instructional mode but rather suggests this method can support and enhance the learning of children with ASD.

Also, providing children with ASD the opportunity to practice reading connected text aloud can increase reading fluency. In two of the included studies, children with ASD and their general education peers increased their oral reading fluency performance by repeatedly reading passages aloud and charting their progress (Kamps et al., 1989; Kamps et al., 1994), a strategy advocated by the NRP (NICHD, 2000). In their review, the NRP found that oral reading fluency practice increased proficiency and fluency with code-focused skills, permitting the reader to focus on constructing meaning.

Because children with ASD may develop decoding skills but continue to have trouble comprehending text, emphasis on meaning-focused skills from the early grades is an instructional priority. Five studies sought to enhance the meaning-focused reading skills of children with ASD by supplementing reading instruction with peer-mediated activities (Dugan et al., 1995; Kamps et al., 1989; Kamps et al., 1994; Kamps et al., 1995; Whalon \& Hanline, 2008). Overall, results suggest that peer-mediated strategies, also recommended by the NRP, can be an effective instructional grouping to increase the meaning-focused (i.e., vocabulary and/or comprehension) skills of some children with ASD as well as their general education peers. Some variability was noted in reading comprehension gains achieved by participants with autism and a moderate cognitive disability (Kamps et al., 1995), but a comprehension strategy was not directly taught. Only one study included direct instruction of a reading comprehension strategy (Whalon \& Hanline, 2008). The authors utilized reciprocal questioning, and children with ASD and their typically developing peers were able to learn a reading comprehension strategy simultaneously.

When considering the instructional methods used to increase meaning-focused skills, specifically direct comprehension instruction, the lack of such interventions targeting individuals with ASD is surprising. That is, when teaching multimethod strategy instruction, it is recommended to initially simplify the task, provide scaffolding through modeling and think aloud, and implement procedural prompts (i.e., self-monitoring checklist, visual cue cards, generic questions; Rosenshine, Meister, \& Chapman, 1996). Such strategies have been incorporated in a number of intervention studies targeting learners with ASD to teach a variety of skills. For instance, children with ASD have increased language development through storybook reading interventions that included modeling and scaffolding procedures (Bellon, Ogletree, \& Harn, 2000; Koppenhaver, Erickson, Harris, et al., 2001; Koppenhaver, Erickson, \& Skotko, 2001). Also, to increase independence, social communication, and/or prosocial behaviors, researchers have incorporated the use of visuals (Krantz, MacDuff, \& McClannahan, 1993; MacDuff, Krantz, \& McClannahan, 1993), scripts (Krantz \& McClannahan, 1993; Sarokoff, Taylor, \& Poulson, 2001; Stevenson, Krantz, \& McClannahan, 2000), and self-monitoring (Koegel \& Frea, 1993; Koegel, Koegel, Hurley, \& Frea, 1992; Mancina, Tankersley, Kamps, Kravits, \& Parrett, 2000) during instruction. Consequently, it is possible that children with ASD can benefit from reading comprehension instruction recommended by the NRP.

For example, the NRP found question generation the single most effective reading comprehension strategy. A child with ASD can be taught to generate questions with a visual cue card paired with a script. This initial structure can be systematically faded to a visual cue paired with a signal word, a visual cue alone, and so forth until the child with ASD generates questions independently. Also, a self-monitoring checklist can be created to prompt the child with ASD when to stop and ask questions during reading. As when teaching a comprehension strategy to any child, the teacher will have to explain the purpose of the strategy and model using the strategy with the intended prompts (i.e., visual cue cards, scripts, signal words, and/or self-monitoring checklist) as he or she thinks through the process aloud.

Another potential intervention to increase the reading comprehension of children with ASD is the development of a cuing system during reading such as anaphoric cuing (O'Connor \& Klein, 2004). Participants with ASD increased their ability to determine the important elements of a story following cues built into text that helped the reader with ASD identify pronouns and corresponding referents. Cuing systems that help clarify abstract and decontextualized language, such as anaphoric cuing, are promising and need further study. Because of the importance of learning to monitor one's own reading comprehension, future research should investigate the impact of teaching students with ASD to independently use the 
anaphoric cuing strategy and should compare the anaphoric cuing strategy with comprehension strategy instruction methods identified by the NRP. It is possible that to increase independence during reading, more instruction teaching the identification of pronouns and referents in text as well as language may be needed.

\section{Future Research}

The NCLB requires that all students have access to reading instruction consistent with reading research (NCLB, 2001). Yet this review clearly demonstrates that research evaluating reading interventions for children with ASD is preliminary and therefore insufficient to guide practice. Consequently, it is critical for researchers to design and evaluate reading interventions based on the science of reading and responsive to the instructional needs of learners with ASD. The following five recommendations are suggested:

1. Evaluate the impact of comprehensive reading instruction on the reading development of children with ASD. Although the included studies investigated one or two components of reading instruction (i.e., phonemic awareness, phonics, fluency, vocabulary, or comprehension), in practice instruction should be comprehensive to include all five. Future research should investigate how children with ASD respond to a comprehensive program in which each reading component is emphasized and explicitly linked, making connections among the five components and the reading process more apparent (e.g., purposefully selecting text that contains sound-letter relationships being taught in phonemic awareness/phonics lessons to build reading fluency, providing opportunities to practice all five components in a number of different contexts and using a variety of texts, and selecting vocabulary based on class readings). In addition, researchers should investigate what if any additional supports (e.g., visual cues, self-monitoring checklists, peer-mediated instruction) children with ASD need to participate in and benefit from a comprehensive reading program.

2. To ensure quality and rigor, researchers should adhere to the quality indicators for research methodology and evidence-based practices established by the Council for Exceptional Children's Division for Research (Odom et al., 2004). For example, to realize the extent that gains are made by individual participants, researchers should include repeated, social validity, and treatment fidelity measures. Future single-subject research studies should include measures in the context of the reading activity as well as on more distant weekly pretest and posttest measures. Continual measures are important in single-subject research because such measures establish a pattern of behavior or instances of deviations from a pattern, thereby producing more detailed information for evaluation (McCormick, 1995). It is also important that generalization is adequately addressed.

3. To gain a better understanding of how individuals with various characteristics spanning the autism spectrum benefit from reading instruction, researchers must include detailed descriptions of participant characteristics (i.e., reading development at the onset of the study, language ability, academic achievement, IQ scores), any individualization of instruction, and the duration and intensity of instruction needed to facilitate progress.

4. Future research should extend the literature base reviewed here. For example, how can computerassisted instruction supplement a comprehensive reading program? How can different instructional arrangements (e.g., one to one, whole group, small group, peer mediated) be combined to facilitate reading acquisition?

5. Future research should investigate not only the effects of comprehension strategy interventions on reading comprehension but also language, social communication, and engagement levels of children with ASD.

\section{Conclusion}

Research addressing the reading skills of children with ASD is just beginning. Researchers should continue this line of inquiry with an emphasis on interventions that address the five areas of reading. In the meantime, teachers should provide reading instruction from the early grades that is consistent with recommendations made by the NRP. Preliminary evidence suggests that learners with ASD can make gains in reading skills when intervention is provided.

\section{References}

* References marked with an asterisk were included in the review. *Basil, C., \& Reyes, S. (2003). Acquisition of literacy skills by children with severe disability. Child Language Teaching and Therapy, 19, 27-48. 
Bellon, M. L., Ogletree, B. T., \& Harn, W. E. (2000). Repeated storybook reading as a language intervention for children with autism: A case study on the application of scaffolding. Focus on Autism and Other Developmental Disabilities, 15, 52-58.

Browder, D., Courtade-Little, G., Wakeman, S., \& Rickelman, R. (2006). From sight words to emergent literacy. In D. Browder \& F. Spooner (Eds.), Teaching reading, math, and science to students with significant cognitive disabilities (pp. 63-91). Baltimore: Paul H. Brookes.

Browder, D. M., Wakeman, S. Y., Spooner, F., Ahlgrim-Delzell, L., \& Algozzine, B. (2006). Research on reading instruction for individuals with significant cognitive disabilities. Council for Exceptional Children, 72, 391-408.

Calhoon, J. A. (2001). Factors affecting the reading of rimes in words and nonwords in beginning readers with cognitive disabilities and typically developing readers. Journal of Autism and Developmental Disorders, 31, 491-504.

Catts, H. W., \& Kamhi, A. G. (2005). Classification of reading disabilities. In H. W. Catts \& A. G. Kamhi (Eds.), Language and reading disabilities (2nd ed., pp. 72-93). Boston: Pearson.

Colasent, R., \& Griffith, P. L. (1998). Autism and literacy: Looking into the classroom with rabbit stories. The Reading Teacher, 51, 414-420.

Colby, K. M. (1973). The rationale for computer-based treatment of language difficulties in nonspeaking autistic children. Journal of Autism and Childhood Schizophrenia, 3, 261-273.

*Coleman-Martin, M. B., Heller, K. W., Cihak, D. F., \& Irvine, K. L. (2005). Using computer-assisted instruction and the nonverbal reading approach to teach word identification. Focus on Autism and Other Developmental Disabilities, 20, 80-90.

Conners, F. A. (1992). Reading instruction for students with moderate mental retardation: Review and analysis of research. American Journal on Mental Retardation, 96, 577-597.

*Dugan, E., Kamps, D., Leonard, B., Watkins, N., Rheinberger, A., \& Stackhaus, J. (1995). Effects of cooperative learning groups during social studies for students with autism and fourth-grade peers. Journal of Applied Behavior Analysis, 28, 175-188.

Ehri, L. C. (2004). Teaching phonemic awareness and phonics: An explanation of the National Reading Panel meta-analyses. In P. McCardle \& V. Chhabra (Eds.), The voice of evidence in reading research (pp. 153-186). Baltimore: Paul H. Brookes.

Frith, U. (2003). Autism: Explaining the enigma (2nd ed.). Malden, MA: Blackwell.

Gough, P. B., Hoover, W. A., \& Peterson, C. L. (1996). Some observations on a simple view of reading. In C. Cornoldi \& J. Oakhill (Eds.), Reading comprehension difficulties: Process and intervention (pp. 1-13). Mahwah, NJ: Lawrence Erlbaum.

Griswold, E., Barnhill, G. P., Myles, B. S., Hagiwara, T., \& Simpson, R. I. (2002). Asperger syndrome and academic achievement. Focus on Autism and Other Developmental Disabilities, 17, 94-103.

*Heimann, M., Nelson, K. E., Tjus, T., \& Gillberg, C. (1995). Increasing reading and communication skills in children with autism through an interactive multimedia computer program. Journal of Autism and Developmental Disorders, 25, 459-480.

Hewett, F. M. (1964). Teaching reading to an autistic boy through operant conditioning. The Reading Teacher, 17, 613-618.

Houston, D., Al Otaiba, S., \& Torgesen, J. K. (2006). Learning to read: Phonics and fluency. In D. Browder \& F. Spooner (Eds.), Teaching reading, math, and science to students with significant cognitive disabilities (pp. 93-123). Baltimore: Paul H. Brookes.
Individuals with Disabilities Education Improvement Act, 20 U.S.C. $\S 1400$ et seq. (2004).

Kamhi, A. G. (2005). Finding beauty in the ugly facts about reading comprehension. In H. W. Catts \& A. G. Kamhi (Eds.), The connections between language and reading disabilities (pp. 201-212). Mahwah, NJ: Lawrence Erlbaum.

*Kamps, D. M., Barbetta, P. M., Leonard, B. R., \& Delquadri, J. (1994). Classwide peer tutoring: An integration strategy to improve reading skills and promote peer interactions among students with autism and general education peers. Journal of Applied Behavior Analysis, 27, 49-61.

*Kamps, D., Locke, P., Delquadri, J., \& Hall, R. V. (1989). Increasing academic skills of students with autism using fifth grade peers as tutors. Education and Treatment of Children, 12, 38-51.

*Kamps, D. M., Leonard, B., Potucek, J., \& Garrison-Harrell, L. G. (1995). Cooperative learning groups in reading: An integration strategy for students with autism and general classroom peers. Behavioral Disorders, 21, 89-109.

Koegel, R. L., \& Frea, W. D. (1993). Treatment of social behavior in autism through the modification of pivotal social skills. Journal of Applied Behavior Analysis, 26, 369-377.

Koegel, L. K., Koegel, R. L., Hurley, C., \& Frea, W. D. (1992). Improving social skills and disruptive behavior in children with autism through self-management. Journal of Applied Behavior Analysis, 25, 341-353.

Koppenhaver, D. A., Erickson, K. A., Harris, B., McLellan, J., Skotko, B. G., \& Newton, R. A. (2001). Storybook-based communication intervention for girls with Rett syndrome and their mothers. Disability and Rehabilitation, 23, 149-159.

Koppenhaver, D. A., Erickson, K. A., \& Skotko, B. G. (2001). Supporting communication of girls with Rett syndrome and their mothers in storybook reading. International Journal of Disability, Development and Education, 48, 395-410.

Krantz, P. J., MacDuff, M. T., \& McClannahan, L. E. (1993). Programming participation in family activities for children with autism: Parents' use of photographic activity schedules. Journal of Applied Behavior Analysis, 26, 137-139.

Krantz, P. J., \& McClannahan, L. E. (1993). Teaching children with autism to initiate to peers: Effects of a script-fading procedure. Journal of Applied Behavior Analysis, 26, 121-132.

Lanquetot, R. (1984). Autistic children and reading. The Reading Teacher, 38, 182-186.

Lord, C., \& Paul, R. (1997). Language and communication in ASD. In D. J. Cohen \& F. R. Volkmar (Eds.), Handbook of ASD and pervasive developmental disorders (2nd ed., pp. 195-225). New York: John Wiley.

Ludlow, A. K., Wilkins, A. J., \& Heaton, P. (2006). The effect of coloured overlays on reading ability in children with autism. Journal of Autism and Developmental Disorders, 36, 507-516.

MacDuff, G. S., Krantz, P. J., \& McClannahan, L. E. (1993). Teaching children with autism to use photographic activity schedules: Maintenance and generalization of complex response chains. Journal of Applied Behavior Analysis, 26, 86-97.

Mancina, C., Tankersley, M., Kamps, D., Kravits, T., \& Parrett, J. (2000). Brief report: Reduction of inappropriate vocalizations for a child with autism using a self-management treatment program. Journal of Autism and Developmental Disorders, 30, 599-606.

Mayes, S. D., \& Calhoun, S. L. (2003a). Ability profiles in children with autism: Influence of age and IQ. Autism, 6, 65-80. 
Mayes, S. D., \& Calhoun, S. L. (2003b). Analysis of WISC-III, StanfordBinet: IV, and academic achievement test scores in children with autism. Journal of Autism and Developmental Disorders, 33, 329-341.

McCormick, S. (1995). What is single-subject experimental research? In S. B. Neuman \& S. McCormick (Eds.), Single-subject experimental research: Applications for literacy (pp. 1-32). Newark, DE: International Reading Association.

Minshew, N. J., Goldstein, G., \& Siegel, D. J. (1995). Speech and language in high-functioning autistic individuals. Neuropsychology, 9, 255-261.

Minshew, N. J., Goldstein, G., Taylor, H. G., \& Siegel, D. J. (1994). Academic achievement in high functioning autistic individuals. Journal of Clinical and Experimental Neuropsychology, 16, 261-270.

Myles, B. S., Hilgenfeld, T. D., Barnhill, G., Griswold, D., Hagiwara, T., \& Simpson, R. L. (2002). Analysis of reading skills in individuals with Asperger syndrome. Focus on Autism and Other Developmental Disabilities, 17, 44-47.

Nation, K., Clarke, P., Wright, B., \& Williams, C. (2006). Patterns of reading ability in children with autism spectrum disorder. Journal of Autism and Developmental Disorders, 36, 911-919.

National Institute of Child Health and Human Development. (2000). Report of the National Reading Panel. Teaching children to read: An evidence-based assessment of the scientific research literature on reading and its implications for reading instruction $(\mathrm{NIH}$ Publication No. 00-4769). Washington, DC: Government Printing Office.

No Child Left Behind Act, 20 U.S.C. $70 § 6301$ et seq. (2001).

Oakhill, J. V., Cain, K., \& Bryant, P. E. (2003). The dissociation of word reading and text comprehension: Evidence from component skills. Language and Cognitive Processes, 18, 443-468.

*O'Connor, I. M., \& Klein, P. D. (2004). Exploration of strategies for facilitating the reading comprehension of high-functioning students with autism spectrum disorders. Journal of Autism and Developmental Disorders, 14, 115-127.

Odom, S. L., Brantlinger, E., Gersten, R., Horner, R. D., Thompson, B., \& Harris, K., for the Division for Research: Council for Exceptional Children. (2004, Fall). Quality indicators for research in special education and guidelines for evidence-based practices: Executive summary. Retrieved July 1, 2007, from http://www.cecdr.org/news.cfm?id=D9775CBD-C09F-1D6FF990DE584CD46125

Perfetti, C. A., Landi, N., \& Oakhill, J. (2005). The acquisition of reading comprehension skill. In M. J. Snowling \& C. Hulme (Eds.), The science of reading: A handbook (pp. 227-247). Malden, MA: Blackwell.
*Rosenbaum, M. S., \& Breiling, J. (1976). The development and functional control of reading comprehension behavior. Journal of Applied Behavior Analysis, 9, 323-333.

Rosenshine, B., Meister, C., \& Chapman, S. (1996). Teaching students to generate questions: A review of the intervention studies. Review of Educational Research, 66, 181-211.

Sarakoff, R. A., Taylor, B. A., \& Poulson, C. L. (2001). Teaching children with autism to engage in conversational exchanges: Script fading with embedded textual stimuli. Journal of Applied Behavior Analysis, 34, 81-84.

Sigman, M., Dissanayake, C., Arbelle, S., \& Ruskin, E. (1997). Cognition and emotion in children and adolescents with autism. In D. J. Cohen \& F. R. Volkmar (Eds.), Handbook of autism and pervasive developmental disorders (2nd ed., pp. 248-265). New York: John Wiley.

Stevenson, C. L., Krantz, P. J., \& McClannahan, L. E. (2000). Social interaction skills for children with autism: A script-fading procedure for nonreaders. Behavioral Interventions, 15, 1-20.

*Tjus, T., Heimann, M., \& Nelson, K. E. (1998). Gains in literacy through the use of a specially developed multimedia computer strategy. Autism, 2, 139-156.

Wahlberg, T., \& Magliano, J. P. (2004). The ability of high function individuals with autism to comprehend written discourse. Discourse Processes, 38, 119-144.

*Whalon, K. J., \& Hanline, M. F. (2008). Effects of a reciprocal questioning intervention on the question generation and responding of children with autism spectrum disorder. Education and Training in Developmental Disabilities, 432, 367-387.

Kelly J. Whalon, $\mathrm{PhD}$, is an assistant professor of special education at the College of William and Mary. Her research interests include interventions to increase the academic achievement and social communication skills of children with autism spectrum disorder.

Stephanie Al Otaiba, $\mathrm{PhD}$, is an associate professor of special education at Florida State University and a faculty associate of the Florida Center of Reading Research. Her research interests include early literacy interventions, response to intervention, and teacher training.

Monica E. Delano, $\mathrm{PhD}$, is an assistant professor of special education at the University of Louisville. Her research interests include social and academic supports for individuals with autism spectrum disorder. 